\title{
Rheological Behavior of Kaolin and Calcium Carbonate \\ Slurries, from a Small Distortion to Rupture
}

by

\author{
Kenji Okada and Yoichi Nagase \\ Dept. of Chem. Eng., Hiroshima Univ., \\ Higashi Hiroshima-shi 724, Japan
}

The rheological behavior of flocculated Kaolin and Calcium Carbonate were examined by a torsional shearing test on a cone-and-plate rheometer. All of these sol type solutions behaved more or less like rigid bodies within small shear and suddenly broken down with increasing shear at several points in the slurries. Break down was progressed intermittently to give a step-wise stress overshoot. When shear rate was less than a limiting value, sliding layer was developed near the solid surface. The phenomenon was supposedly due to the dilatant nature of the slurry. Over the limiting shear rate, stress break-down occurred at once and as a whole without any stress overshoot, that is quite similar to a Binghammodel fluid. Steady state properties also varied at this limiting shear rate.

\section{カオリンおよび炭酸カルシウムスラリーの低ひずみ から破断に至る間のレオロジー的性質}

\author{
岡田賢治・長瀬 洋 一*
}

(原稿受理：1981年12月18日）

\section{1. 緒言}

前報1に引引きつづいて，乙てでは疎水性粒子，とくに沈降を出 来るだけ防ぐためによく凝集したゾルについて, 静止から定常流 動に至る過程の特徴点をスラリー層のひずみ状況の可視化と対比 しながら述べる。

\section{2. 試料および測定装置}

結晶構造等性状がよく研究されているカオリン（ジョージア 産 $)^{2), 3)}$ と炭酸カルシウムを選んだ. 後者は前者に比して粒子形状 が単純かつ粗大である. 本カオリンは微量の塩酸添加によって強 固な凝集体を生じ $(\mathrm{pH}<4)$, カード八ウス構造をとると推定され

* 広島大学工学部 化学工学教室 $\overline{\mathbf{T}} 724$ 東広島市西条町大字下見
た。乙の状態のもの，およびカオリンを水中に単に分散（pH = 5.4)させ，乙れにカチォン系有機高分子凝集剤を加えて凝集さ せたものの二種類を用意した. 炭酸カルシウムは単に水中で分散 させるだけで凝集した。いずれのスラリーも粒子の沈降を防ぐた めに，1 週間以上放置しても上澄液が出ない程度の高濃度範囲を 測定対象とした。応力ーひずみ一ひずみ速度の測定装置, 測定方法 抢よび試料側面の変形状態可視化方法等は前報1)之同様である. ただし，上記試料はいずれも後記するように固体面とスラリーの 界面ですべりを起こしやすいあのであった．すべりを防ぐ目的で 円錐と平板の両表面に溶剂で, 低濃度に稀釈した接着剂中に少量 の試料粉体を混入した溶液を塗布した，乾燥後の表面凹凸は円錐 一平板間隙厚さに比して無視しうるが，す心゙りをなくするのに効 果があった。 


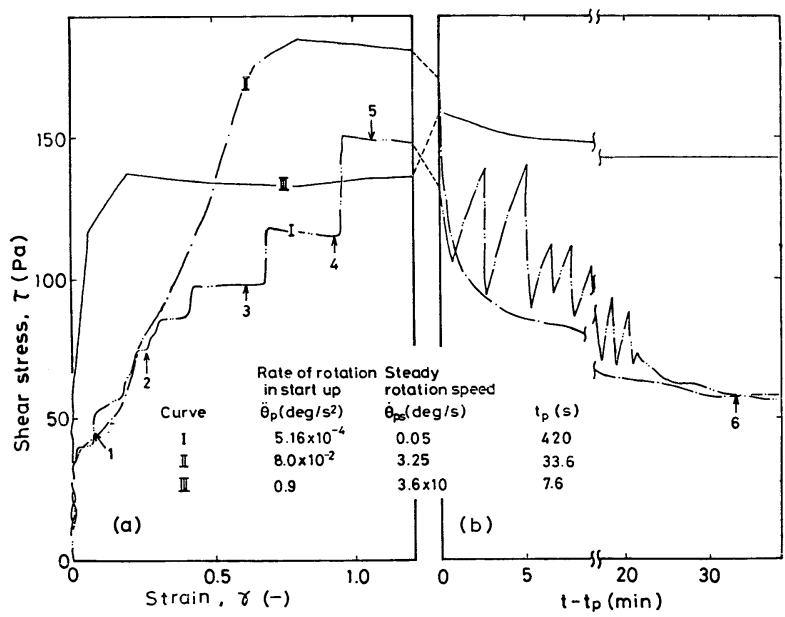

Fig. 1 Overall profiles of stress break-down of quietly setted sample : Kaolin 28.2 vol\%, $t_{p}:$ appropriately selected constant.

\section{3. 結果と考 察}

\section{$3 \cdot 1$ すべり破壊から定常流動に至る間の挙動*1}

三種類のスラリーはいずれも極めて類似な挙動を示したので, 以下には典型例としてカオリンの塩酸酸性凝集体 $(28.2 \mathrm{vol} \%$ 溶 液）について記す。

試料は仕込んで後 5 分後に測定した。測定結果は放置洔間を変 えても変わらなかったためである。前報1のモード工を用いて静 䁂状態から秝じりひずみを与え, 破断し, 定常流動江至らしめた ときの测定結果を Fig. 1 亿示す. (a) 図の横軸は便宜的にひずみ ケをとっている，低ひずみ域における著しい特徽は，静止状態の スラリーが応力を与えてもほとんど変形せず，ある点，(a) 図の 場合 $\fallingdotseq 40 \mathrm{~Pa}$ で急にすべり, 塑性モデルに極めて近い挙動を示し たととである．ただし，すべりは一度に起こるのではなく，幾度 あ間欠的に起こる．乙のことは低加速度で回転を立ち上げたとき *2の結果（曲線Ｉ）によく表杖てる。すべる前までてが増加し，

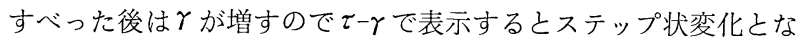
る. この間に応力が増加し最大值に達する.

この傾向は曲線 II みられるように， $\ddot{\theta}_{p}$ と共に増加するが（間 欠的なすべりの回数が增すために $\tau-\gamma$ 曲線で表すと滑らかにな る), 曲線 I, II共に最大点をすぎて後はチキソトロピー的に $\tau$ は低下し定常状態に至っている．曲線Ｉではチキソトロピー変化 においてもな擆しい応力変動がみられ，一方定常状態に打ける 忘力は両者の定常回転速度が，一桁以上屯相違しているにもかか わらずほぼ等しいことが注目される。曲線吕は $\ddot{\theta}_{p}$ を更に大きく した場合で, このときはむしろ応力が漸次增加し，またチキント ロピー変化はなくなっている．てのように静置からねじりひずみ を経て定常流動洼する間の応力変化は, $\ddot{\theta}_{p}$ と定常回転速度 $\dot{\theta}_{p s}$ に応じて多様に変化し，その挙動はベントナイトょりあむしろ複 雑であった，詳細は省略するが，低ひずみ域で正弦波状のひずみ を加えた結果はヒステリシスは示すすのの，一周期でとに違った

*1 “すべり”と表現した意味については，前報1) 7 頁脚注を参照され たい.

*2 前報1) に記したようにモード【では， $\theta_{p}=0$ から一定の加速度で回 転を立上げてゆく方法をとっている。
履歴を与え，かつ再現性の乏しいあのであった。

\section{$3 \cdot 2$ 可視化との対応}

上記の多様な結果を解明するために，試料側面におけるスラリ 一の変形過程を可視化観察した。結果の一例を Fig. 2 に示す. 図は 3 本のマーク線に注目し，乙れが静止（曲線 0 ）から Fig. 1 曲線 I 上の点 1 および 3 におけるすべり状態に至るまでを, $\theta_{p}$ を 一致させて重㸚焼きしたあのである.

曲線 1 は最初直線であったものが, $\tau=40 \mathrm{~Pa}$ 亿おいて突然すべ つた直後の変形状態である. 平板に近い層は全く変形しておらず, 上方程変形量が大きいことが注目される.曲線 3 は平板近くの層 が再度哭然すべった直後の写真であるが，曲線 1 から 3 亿至る間 の観察によると円錐直下では連続的なすべり流動が起っている之 判断された. 多数の写真結果をまとめて Fig. 3 亿示す. (a )図 （I）はFig. 2 亿対応しており，また図上の各曲線と Fig. 1 曲 線I上の各点が対応している，上述のような平板に近い部分にお ける突発的なすべりが再び起って, 曲線 4 の階段状の変形曲線を 与え, 一方円錐面近傍ではすべり流動が著しく進行して曲線 4 , 5 となった。このようにひずみを与え始めてしばらくの間は塑性 的で間欠的な破壊と, 冈錐近傍におけるすべり流動との競合状態

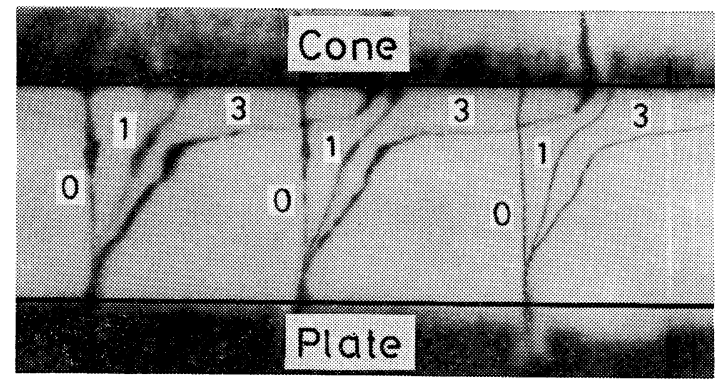

Fig. 2 Yielding behavior visualized by marked lines on sample side surface. (a) Distortion and unsteady flow
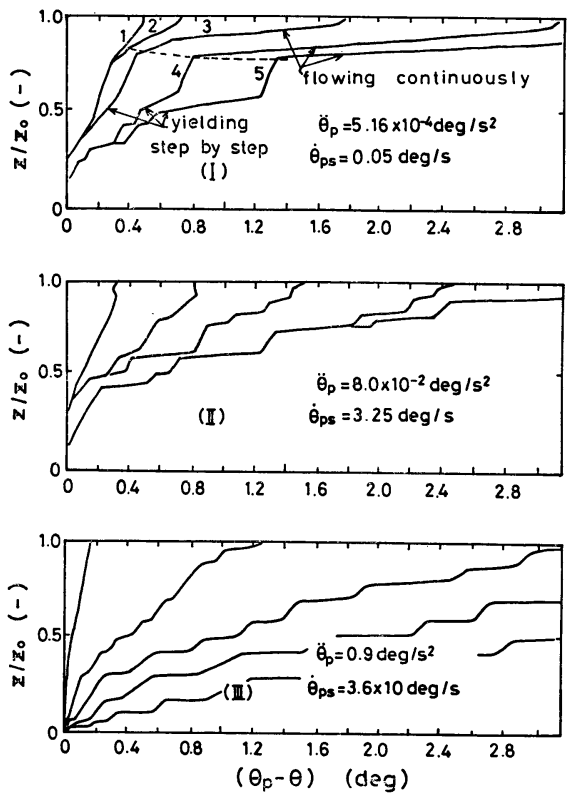

(b) Steady flow

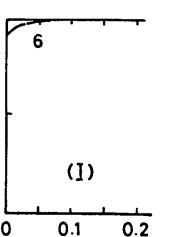
$\left(\dot{\theta}_{p s}-\dot{\theta}\right)($ deg/s $)$

Fig. 3 Illustrations of yielding schemes and steady flow profiles with shear rate. 
が実現し，その境界面は大約 (a) 図(I)上に示す点線にあると判 断された。乙の状態は曲線 5 までで, 乙れ以後は円錐面近傍にお ける流動のみがみられるようになる。ために流動部分を除く層の 大部分はあは吊変形屯起こさず，相対的に剛体化し，単に回転す るにとどまる。一方, 流動部の幅は時間と共に狭まってゆき, 定 常状態に達したときには層全体の約 $1 / 7$ が流動しているに過ぎな くなる，乙のときの速度プロフィールの概要は (b ) 図 ( I )のよう であった。

曲線 5 は Fig. 1 では $\tau$ の最大点にほぼ等しいととに注意する と, 最大点までは一部流動化しながらもスラリ一層の塑性的な破 壊が進行してゆくことに, 最大点以後は円錐面付近での流動のみ が起こり，その幅が時間と共に減少することが Fig. 1 ではチキ ソトロピー的な変化として测定されなたと解釈出来る. 曲線 5 に 至るまでは, 初めのすべり点で再度すべりが起こると同時に他の 部分で新たなすべりが起っているので,すべりが起った後に部分 的な硬化がある.ために Fig. 1 でて は点 5 まで增加したもの之 考えられる。

立ち上りの回転角加速度がある限界值以下であれば, 現象は上 記と基本的飞变わらない，その一例は（a ）図(II)にみることが出 来る. $\ddot{\theta}_{p}$ が大になるに伴なって塑性破壊を示す階段状きざみ段 数は増し, また定常状態の流動幅と速度プロフィールが変わるだ けである。しかし， $\ddot{\theta}_{p}$ が限界值以上になると，スラリ一層のほ ぼ全体が一度に塑性破壤し，以後多少の破壊が累加するものの， 全体としては直ちに流動に移行し, ビンガムモデルに極めて近い 挙動を示した。したがって，チキソトロピーはほとんどみられな くなる. Fig. 1 曲線III抢よび Fig. 3(a) の（III）がこれに相当す る. 以上の傾向は本実験で用いたいずれの試料についても同様で あったので, 微粒子分散系に大なり小なり共通する一つの特徵で あろうと推察される。

\section{$3 \cdot 3$ ダイラタンシーとチキソトロピー}

草 が小さいときは，狭い幅のみが流動するようになる点は前 報ベントナイト1)之同様であった．

このととは本実験および前報ベンナイト1のいずれにしてむ徐 々にせん断を与えている間に，スラリ一内部の構造と応力状態変 化が進行することを示しているのであるが，乙れを解明するとと は困難である。そこで, 次の二つの問題について検討した。第一 はスラリー層が破断する以前の応力場の不均一が破断の進行に伴 なって強調されるとみるもので, 破断以前を一様等方弾性体と仮 定すると, 解析結果は円錐面に近づくほど主せん断応力, ひずみ エネルギーが増し，円錐面上ではそれぞれ平板面より $0.3 \%, 0.7$ \%大きかった (Appendix 参照). 第二は実験は固液分離が起こら ない程度に高濃度の試料について行ったが, それでも静置したと きに形成したネットワークが破壊されたときに局所的に沈降が促 進され，試料上面近傍の濃度が多少低下するために上側の円錐面 近傍が流動するとするものである*1. これの検討は第一の問題の 解明屯合わせて円錐を下側，平板を上側にして再テストするのが

*1 この仮説によると試料層の下側部分については濃度が增し，粘度 上昇をもたらすことになるので，この部分に関してはダイラタン シー変化となる。一方, 試料層の表面付近において観察される現 象は，ダイラタンシー変化に付随するものとみることが出来る. 試料層が不均質になったとみなすことに本仮説の基礎があるので 単純な概念を適用出来ないが，上記の意味でここでは（広義の） ダイラタンシーとよぶことにする。
よいと考えられた。

結果は上側平板面で Fig. 3 と全く同様なすべりを起こした。 ベントナイトは同じテストで前報1)之類似の結果をえた。また， カオリンでむより高濃度のあのは極低加速度で立ち上げたときに, 塑性的な破壊を起こす以前に上面ですべり流動が認められるすの の, $\ddot{\theta}_{p}$ がやや大きくなると, 部分的流動あるいは全面流動 (Fig. 3 (II) と (III)) の区別が明確でなくなる．乙れらの結果はいずれ あ上記第二の仮定を支持していると考えられる.

以上をまとめて次の推論がえられる．前述のように前報1)の実 験を含めて, 実験は固液分離しない濃度で行うよう留意したが, 本実験で用いた系はベントナイトに比して粒子径は大きくそれだ け不均質であるために，乙こにいうダイラタントな変化*1 が契機 になって試料層上部の濃度低下が進行し，ての部分のみが流動す るために応力測定に扔いてはチキソトロピーとして検出される. $\ddot{\theta}_{p}$ がこの時定数よりも十分大きいとき，チキソトロピーは検出 されず, Fig. 1 曲線亚のようにビンガムモデルに近づく.ベント ナイトについてもチキソトロピーとして検出される流動域の急速 な狭まり過程は, 本報の場合も同様に固液分離の促進過程に対応 しているのではないかと推察される。ただし，ベントナイトはは るかに均質かつ応力場もほとんど一様 (Appendix) であるので, たまたま構造強度の弱い部分がすべり，チキソトロピーのきっか けを与えるのであるう。

\section{4. 定 常 流動 特 性}

定常流動特性の測定結果 Fig. 4 亿示す。図にはカオリンの 他炭酸カルシウムの测定結果屯示している. 図上の逆三角印は, 一旦高速回転を与えてから所定の回転数に下げたときの結果であ る. また, 点I 以上の回転数では試料が全面流動することを可視 化によって確認出来た点，I-II間はFig. 3(b) の（II）に対応する

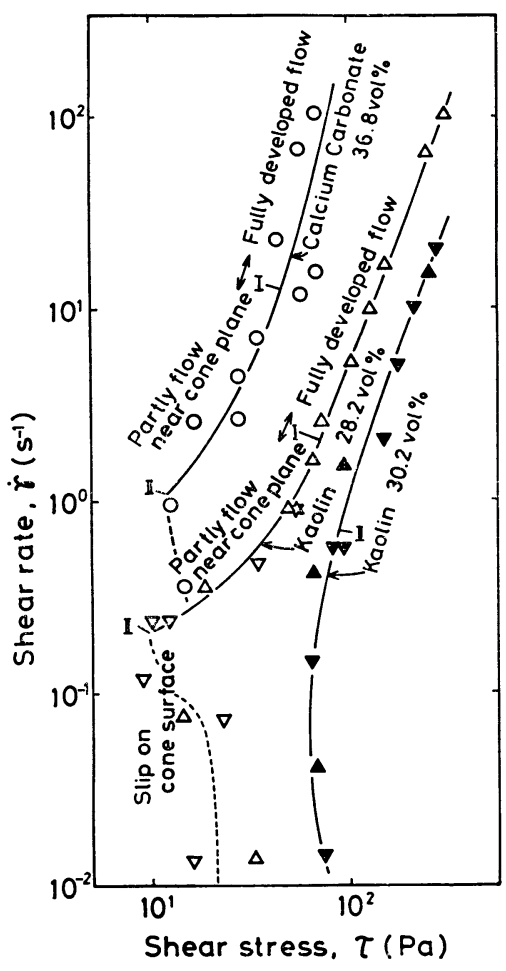

Fig. 4 Steady state flow properties. 


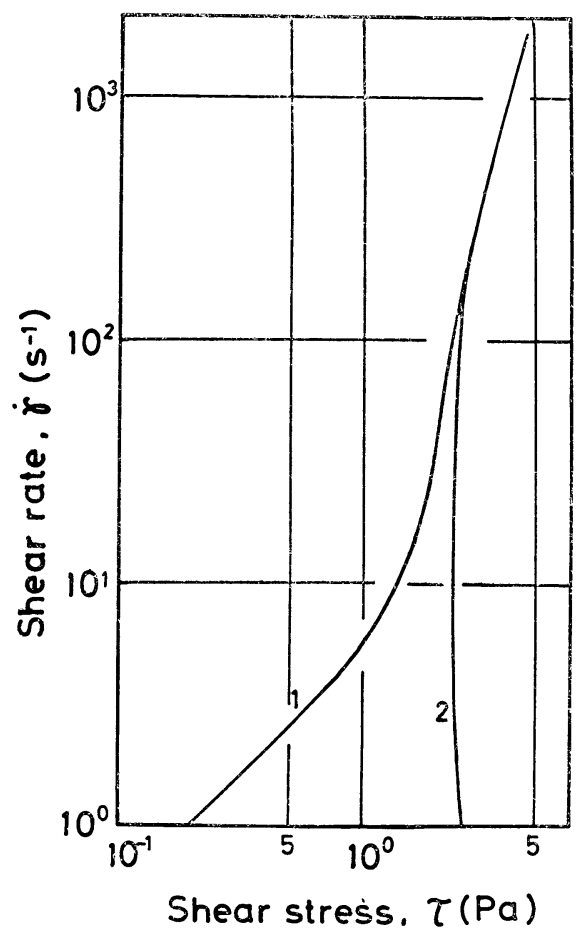

Fig. 5 Flow behavior presented by Thomas.

状態，II以下では円錐面直下のでく狭い幅でのみ流動している状 態である．前項までに例示したカオリン 28.2 vol\%についてみる と, ほぼ点 Iおよび点IIを境にして定常特性にかなり顕著な変化 がみられる. 点I以上では擬塑性的, 点I以下は真の $\dot{\gamma}$ 表して いるとはいえないが，I-II 間で見掛け上ニュートン的流動に類

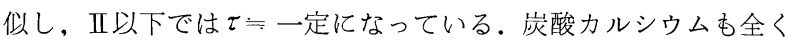
類似な傾向を示す. 高濃度のカオリンは, 前述のように可視化に よって部分的流動と全体にわたる流動との区別がつきにくかった。 このととに対応して，カオリン 30.2 vol\%の場合はニュートン流 動類似の領域がみられなくなっている. また, 可視化結果はかな り相違するが, $30.2 \mathrm{vol} \%$ の場合の定常流動特性は前報1)ベント ナイトのそれと結果的に類似している.

Thomas $^{4)}$ は毛細管型粘度計を用いて, 酸化トリウムなどの定 常流動特性を測定し Fig. 5 の結果を与え, 物質によって曲線 1 のタイプと 2 のタイプのいずれか, または両者の中間的な曲線を とるとしている. 彼の結果と Fig. 4 とを対比すると, 曲線 1 亿 近い結果を示したものは比較的低濃度で, ダイラタントな変化を 起こしやすかったもの, 高濃度になりダィラタンシーを起こしに くくなる程曲線 2 亿近づくあのと推察される。

\section{5. 結}

\section{論}

まだ断定しかねるところああるが，大要次の結論がえられた。 よく凝集した微粒子のスラリーは静置状態で剛体的であり, あ る応力で塑性的に降伏する．ひずみの付加加速度が小さいときは， 降伏が位置的にあ時間的にあ離散して起こり, 乙の間は応力が増 加し続ける. その後ダイラタントな固液分離化傾向が進展するが, 測定結果としてはチキソトロピー挙動として検出される.ひずみ 付加速度が大きくなると, 試料層全体にわたって一斉に降伏する ので, 上記のような応力増加やチキソトロピーはみられない，定 常流動特性は, 層全体が流動しているときとそうでないときで明
らかな相違がみられた。

ただし, チキソトロピーが構造的にみたときのダイラタンシー に起园するとの見解については，まだ多くの確認が必要であろう が, あしての見解が妥当であるとすると, 同様な現象は程度の差 はあれ測定装置・方法に関せず検出され，測定結果の多様性をむ たらす一つの要因にならうと考えられる.

\section{付 録}

試料は等方等質弾性体でありかつ単純ねじりせん断にある軸対 称問題之仮定する．乙のとき円筒座標表示による応力の釣合い方 程式の $\theta$ 成分は $r, z$ 成分と独立する ${ }^{5)} . \theta$ 成分を変位 $u_{\theta}$ を用い て表示すると式 (1) をうる.

$$
\frac{\partial^{2} u_{\theta}}{\partial r^{2}}+\frac{1}{r} \frac{\partial u_{\theta}}{\partial r}-\frac{u_{\theta}}{r^{2}}+\frac{\partial^{2} u_{\theta}}{\partial z^{2}}=0
$$

境界条件は $u_{\theta}$ を平板一円錐の相対変位にとり，

$$
\left.\begin{array}{l}
z=0 \text { (平板上) で, } u_{\theta}=(\theta-\alpha) r \\
z / r=\tan \beta_{0} \text { (円錐上) で, } u_{\theta}=0
\end{array}\right\}
$$

ここに， $\beta_{0}$ は円錐一平板の間隙角となる.

解は式 (3) で与えられる.

$$
u_{\theta}=A\left\{B-\eta \sqrt{1+\eta^{2}}-\ln \left(\eta+\sqrt{1+\eta^{2}}\right)\right\} \cdot r
$$

ただし，

$$
\begin{aligned}
& \eta=z / r=\tan \beta \\
& A=\frac{(\theta-\alpha)}{\tan \beta_{0} \sqrt{1+\tan ^{2} \beta_{0}}+\ln \left(\tan \beta_{0}+\sqrt{1+\tan ^{2} \beta_{0}}\right)} \\
& B=\tan \beta_{0} \sqrt{1+\tan ^{2} \beta_{0}}+\ln \left(\tan \beta_{0}+\sqrt{1+\tan ^{2} \beta_{0}}\right)
\end{aligned}
$$

これより,ひずみと応力の各成分は式 (4)〜 (7), また主せん断応 力 $\tau_{p}$, ひずみエネルギーWはそれぞれ式 (8), (9) で与えられる.

$$
\begin{aligned}
& \gamma_{z \theta}=-2 A \sqrt{1+\eta^{2}} \\
& \gamma_{r \theta}=2 A \eta \sqrt{1+\eta^{2}} \\
& \tau_{z \theta}=-2 A G \sqrt{1+\eta^{2}} \\
& \tau_{r \theta}=2 A G \eta \sqrt{1+\eta_{z}} \\
& \tau_{p}=2 A G\left(1+\eta^{2}\right) \\
& W=2 A^{2} G\left(1+\eta^{2}\right)^{2}
\end{aligned}
$$

式 (4) （9）に示されるように，ひずみと応力はすべてクに関して 相似である. 主応力は円錐角 $\beta\left(=\tan ^{-1} \eta\right)$ に直交する面上, $\tau_{p}$ はこの上で $\theta$ 方向にある.すべての応力とひずみエネルギーは と共に增加するが, 本装置の $\beta_{0}=3.34^{\circ}$ における円錐面上の $\gamma_{z \theta}$, $\tau_{z \theta}, \tau_{p}$ およびWは平板上のそれらに比してそれぞれ $0.2 \%, 0.2$ $\% ， 0.3 \%$ 扔よび0.7\%増加する.したがって, 通常の測定におい ては前報 ${ }^{1)}$ 式 (1) (2) が成立する.

（1981年10月28日，第29回レオロジー討論会にて発表）

\section{文献}

1）岡田賢治, 高木基實, 長瀬洋一，日本レオロジー学会誌, 投稿中.

2）梅屋薰, 磯田武信, 小泉源三, 加藤和男, 材料, 21(224), 469 (1972).

3）粉体工学研究会, 日本粉体工業協会編, “粉体物性図説”, p. 195 (1975) 産業技術センター刊.

4) Thomas, D.G., A. I. Ch. E. Journal, 6(4), 631 (1960).

5) Timoshenko, S., and J.N. Goodier, "Theory of Elasticity", 2nd edition, p. 305 (1951) Mc-Graw Hill. 